\title{
Oxindoles and Copper Complexes with Oxindole-Derivatives as Potential Pharmacological Agents
}

\author{
Giselle Cerchiaro ${ }^{\#}$ and Ana Maria da Costa Ferreira* \\ Departamento de Química Fundamental, Instituto de Química, Universidade de São Paulo, \\ Av. Prof. Lineu Prestes, 748, 05508-900 São Paulo-SP, Brazil
}

\begin{abstract}
Oxindóis são compostos endógenos encontrados em fluidos e tecidos de mamíferos. Particularmente, isatina ( $1 H$-indol-2,3-diona) e seus derivados vêm mostrando uma grande variedade de efeitos no meio biológico, incluindo a inibição de monoamina oxidase, atividade bactericida, fungicida, antiviral e antiproliferativa. Pesquisas mais recentes descrevem estes compostos como inibidores de quinases, uma classe de proteínas envolvidas em várias etapas do ciclo celular. Nesta revisão, complexos de cobre(II) com ligantes derivados de oxindóis são discutidos como potenciais agentes antitumorais, em comparação com outros complexos, com base na proposição de se aliar as propriedades redox e coordenativas do metal à capacidade de afetar os processos de angiogenese e apoptose já demonstrada por esse tipo de ligante.
\end{abstract}

Oxindoles are endogenous compounds found in mammalian body fluids and tissues. Particularly, isatin ( $1 \mathrm{H}$-indole-2,3-dione) and its derivatives have shown a variety of biological effects, including inhibition of monoamine oxidase, antibacterial, antifungal, antiviral and antiproliferative activities. Recent reports have described these compounds as efficient inhibitors of kinases, a class of proteins involved in many steps of the cellular cycle. Here, some copper(II) complexes with oxindole-derived ligands are discussed as potential antitumoral agents, in comparison to other complexes, based on the proposal of a synergistic effect on adding the metal coordinating and redox properties to the already demonstrated capability of these ligands to influence the angiogenesis and apoptosis processes.

Keywords: copper, oxindole derivatives, metallodrugs, apoptosis, redox regulation

\section{Introduction}

A significant rising interest in the design of metal compounds as drugs and diagnostic agents is currently observed in the area of scientific inquiry appropriately termed medicinal inorganic chemistry. ${ }^{1}$ Investigations in this area focus mostly on the speciation of metal species in biological media, based on possible interactions of these metal ions with diverse biomolecules, in an effort to contribute to future development of new therapeutics or diagnostic agents. ${ }^{2-4} \mathrm{~A}$ wide range of metal complexes are already in clinical use, ${ }^{5}$ and encourage further studies for new metallodrugs, such as metal-mediated antibiotics, antibacterial, antiviral, antiparasitic, radiosensitizing agents, and anticancer compounds. ${ }^{6}$ However, their mechanisms of action are often still unknown. Recently,

*e-mail: amdcferr@iq.usp.br

"Present Address: Universidade Federal do ABC, Santo André, SP. more than a thousand potential anticancer metal compounds, from the National Cancer Institute (NCI) tumor-screening database, were analyzed based on putative mechanisms of action, and classified into four broad classes, according to their preference for binding to sulfhydryl groups, chelation, generation of reactive oxygen species, and production of lipophilic ions. ${ }^{7}$

Additionally, increasing knowledge of the biological activities of simple metal complexes guided many researchers to the development of promising chemotherapeutic compounds which target specific physiological or pathological processes. Many potential antitumoral agents have been investigated based on their anti-angiogenesis or pro-apoptotic behaviour. These studies involve both designed and natural products, in association with essential metal ions such as copper, or iron. ${ }^{8}$

Disturbed redox equilibrium, described as oxidative stress, is usually pathological, and changes in the oxidation 
state of cells over long time periods usually cause damage to biomolecules (lipid peroxidation, protein oxidation, DNA strand breaks). Intracellular redox state unbalance in cells is responsible for induction of apoptosis, an ordered sequence of events that lead to cell programmed death. Apoptosis can be triggered by physical or chemical stimuli, such as UV and $\gamma$-radiations, hypoxic conditions, and prooxidant agents. ${ }^{9}$ The cell-suicide program is then activated through induction of gene transcription, following DNA damage, and inducing protein repair or the cell cycle arrest. If damaged DNA is not repaired, the induction of caspasedependent apoptosis occurs, followed by removal of apoptotic cell through macrophages or neighbouring cell phagocytic-activity without inflammation.

In this context, redox active complexes can provide an alternative tool for redox regulation as a therapeutic basis, interfering in oxidative trigger mechanisms in cells. Specific ligands can be useful in the modulation of metal ion reactivity, by modifying their redox potential, hydrophilic or lipophylic characteristics, or saturating its coordination sphere, and therefore avoiding undesirable interactions with cell components. Particularly, copperbased compounds have been investigated on the proposal that endogenous metals may be less toxic. ${ }^{10}$

Copper is an essential trace element and plays a crucial role in living systems, performing a wide variety of functions in the active site of proteins and enzymes involved in metabolism. ${ }^{11}$ However, copper can also become toxic and potentially carcinogenic if not properly bound. Its redox reactivity may lead to severe injury to cells through oxidation of proteins, lipids, and nucleic acids, with generation of reactive oxygen species (ROS), that is, superoxide ion, hydrogen peroxide, and hydroxyl radical. ${ }^{12}$ Indeed, copper ions in mammals are tightly bound to protein carriers and transporters. Copper homeostasis is a highly regulated process, and a variety of specific chaperones with high affinity for copper ensure that it is efficiently coordinated, avoiding interactions with cellular components. ${ }^{13}$ As a consequence, a direct exchange of copper between specific proteins is observed,${ }^{14}$ and virtually nil concentrations of free or simple ligand-bound copper ions are found in fluids or inside the cells. ${ }^{15}$ Therefore, living cells seem to be well prepared to deal with copper ions, having an appropriate protein machinery that provide different ways for their absorption, transport, storage, and detoxification. ${ }^{16}$

Based on these arguments, different copper compounds with diverse ligands have been isolated and studied as potential therapeutic agents. In this paper, interesting compounds, the oxindoles, that have already shown beneficial biological effects are discussed as suitable copper ligands, capable of adequately modulating the metal properties.

\section{Oxindoles and their Biological Activities}

Oxindoles are endogenous compounds found in mammalian body fluids and tissues, ubiquitously distributed in the central nervous system, that have shown an extensive range of biological effects, including antibacterial, antifungal, anticonvulsant, antiviral, and antiproliferative activity. ${ }^{17}$ Particularly, isatin ( $1 H$-indole2,3-dione; 2,3- dioxoindoline; or indoline-2,3-dione) was discovered in the nineteenth century as an oxidation product of indigo, ${ }^{18}$ and it is probably the first example of tautomeric substance to be reported. Its tautomeric forms were formerly proposed in 1882, exhibiting two chemically dissimilar carbonyl groups, a lactam-carbonyl $(\alpha)$, and a keto-carbonyl $(\beta)$, as shown in Figure $1 .{ }^{19}$<smiles>O=C1Nc2ccccc2C1=O</smiles>

2,3-dioxoindoline

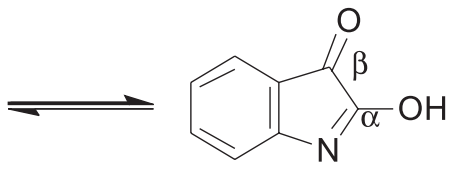

2-hydroxy-indolin-3-one
Figure 1. Tautomeric forms of $1 H$-indole-2,3-dione.

Isatin is present in the brain and other tissues in humans, and the oxindole moiety is also found in natural products in some plants..$^{20}$ The metabolism of isatin in humans is not yet well elucidated. It has been suggested that tryptophan and/or phenylalanine is converted by intestinal bacteria into indole, which is then absorbed and metabolized in the liver to isatin via 3-hydroxyindole. ${ }^{21}$ Indoxyl and isatin further undergo spontaneous oxidation and dimerization forming indigoid pigments, indigo and indirubin, which are also excreted in urine. On the other hand, a carbonyl reductase was identified as a major mediator in metabolic pathways of isatin, and probably plays a critical role in its biological activities. ${ }^{22}$ Oxindoles usually have a broad range of pharmacological actions, being already described as both anxiogenic and sedative agents, ${ }^{23}$ as antagonists of guanylate cyclase-coupled atrial natriuretic peptide receptor, ${ }^{24}$ and as potent inhibitors of monoamine oxidase B. ${ }^{25}$

Schiff bases of $N$-methyl and $N$-acetyl isatin derivatives with different aryl amines were prepared and screened for anticonvulsant activity. The compounds with bromo substituent in the isatin ring and chloro substituent in the phenyl ring exhibited a broad-spectrum activity, and seem to be good prototypes for the development of new drugs against epilepsy. ${ }^{26}$ Some hydrazones, Schiff and Mannich bases of isatin have also exhibited significant anticonvulsant 
activity, and based on these results some structural features responsible for interaction with the receptor site were established within a suggested pharmacophore. ${ }^{27}$ Good antibacterial and antifungal activities of Schiff and Mannich bases derived from isatin and thiolyl-thiosemicarbazide have also been described. ${ }^{28}$ Some examples of these compounds are shown in Figure 2.<smiles>[R]N=C1C(=O)N([R])c2ccc([R])cc21</smiles>

$$
\mathrm{R}^{1}=\mathrm{H}, \mathrm{CH}_{3}, \mathrm{Cl}, \mathrm{Br} \text { or } \mathrm{NO}_{2}
$$
$\mathrm{R}^{2}=4$-Br-phenyl, 4-methylphenyl, 1-naphthyl, etc. $\mathrm{R}^{3}=\mathrm{H}$ or $-\mathrm{CH}_{2}-\mathrm{N}\left(\mathrm{C}_{6} \mathrm{H}_{5}\right)_{2}$<smiles>[R]c1ccc2c(c1)/C(=N/NC(=S)Nc1nc(-c3ccc(Cl)cc3)cs1)C(=O)N2[R]</smiles>

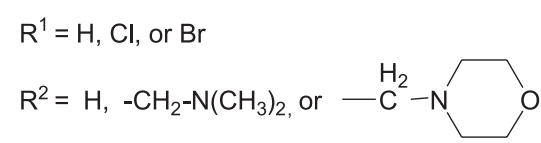

Figure 2. Some oxindole-derived compounds with anticonvulsant, antibacterial and antifungal activities.

Antiproliferative and proapoptotic actions of isatin and 5-hydroxyoxindole, but not oxindole, have been described for different tumoral cells, at concentrations lower than $10^{-6} \mathrm{~mol} \mathrm{~L}^{-1} .^{29}$ Primary cytotoxicity evaluation of a series of 5-nitroindole-2,3-dione-3thiosemicarbazone derivatives has indicated that these compounds could also act as potential new anticancer agents, since they reduced the growth of different human tumor cell lines to $\leq 32 \% .{ }^{30}$

Additionally, indole and isatin oximes can be easily prepared and are widely used as precursors in fine organic synthesis, leading to many different products, such as amine, ether-, nitrile-, and oxazole-derivatives, ${ }^{31}$ which were also proposed as therapeutic agents for coronary and ischemic heart disease, cardiac arrhythmia and hypertension, ${ }^{32}$ and as antidepressants. ${ }^{33}$

\subsection{Synthetic oxindoles as enzyme inhibitors}

A new series of isatin derivatives (see Figure 3) was designed, by utilizing a combination of protein structure- based drug design, molecular modelling, and structureactivity relationship (SAR). These compounds were subsequently synthesized and evaluated as inhibitors of human coronavirus $3 \mathrm{C}$-like and rhinovirus proteases. ${ }^{34}$ Modelling studies of these protein-inhibitor complexes lead to some interesting conclusions about placing specific groups at $\mathrm{N}-1$ and $\mathrm{C}-5$ position. The $\mathrm{C}-2$ carbonyl of isatin was envisioned to react in the active site of human rhinovirus (HRV) 3C protease with the cysteine responsible for catalytic proteolysis, thus forming a stabilized transition state mimic.

More recently, a series of novel oxindoles were discovered as efficient HIV (human immunodeficiency virus) non-nucleoside reverse transcriptase inhibitors. Systematic structural modifications of the lead molecule defined its SAR, and permitted the identification of increased antiviral activity at the early stages in infection. ${ }^{35}$ These studies suggested that both the NH and the carbonyl oxygen moieties are crucial for the antiviral activities, and also demonstrated that the cyclopropane moiety is critical in optimizing effective molecular interactions (see Figure 4).<smiles>[R]c1ccc2c(c1)C(=O)C(=O)N2[R]</smiles>

$$
\begin{aligned}
& \mathrm{R}^{1}=\mathrm{H}, \mathrm{CH}_{3}, \mathrm{CH}_{3} \mathrm{CH}_{2} \mathrm{CH}_{2}, \mathrm{n}-\mathrm{C}_{4} \mathrm{H}_{9} \text {, etc. } \\
& \mathrm{R}^{2}=\mathrm{I}, \mathrm{CO}_{2} \mathrm{H}, \mathrm{CO}_{2} \mathrm{CH}_{3} \text {, or } \mathrm{CONH}_{2}
\end{aligned}
$$

Figure 3. Structure of some oxindoles that act as virus protease inhibitors.<smiles>[R3]c1ccc2c(c1)C1(C(=O)N2)C(C(=O)OCC)C1([R])C</smiles>

$$
\begin{aligned}
& \mathrm{R}^{1}, \mathrm{R}^{2}=\mathrm{H}, \mathrm{Me}, \text { or } \mathrm{Et} \\
& \mathrm{R}^{3}=\mathrm{Br}, \mathrm{Cl}, \mathrm{CN}
\end{aligned}
$$

Figure 4. Structure of some oxindoles with anti-HIV activity.

Further, some indolinone-derivatives were prepared by attaching different chemical substituents to an oxindole-core, and were observed to act as efficient inhibitors of protein tyrosinase kinases (PTKs). ${ }^{36}$ These protein kinases are critical components of signalling pathways in the control of cell proliferation and differentiation, and enhanced PTK activity has been 
implicated in many human cancers. ${ }^{37}$ Thus, selective inhibitors of this class of proteins can have considerable therapeutic value, as compounds SU4984 and SU5402, shown in Figure 5. Some oxindole and aza-oxindoles were synthesized and described as potent inhibitors of TrkA tyrosine kinases, a subclass in this family of enzymes, such as compounds A and B in Figure 5. Some substituents with similar scaffold in these compounds can increase the selectivity for TrkA inhibition over CDK2, another class of kinase proteins. As an example, compound A showed $\mathrm{IC}_{50}=0.008 \mu \mathrm{mol} \mathrm{L} \mathrm{L}^{-1}$ for TrkA, and $10.4 \mu \mathrm{mol} \mathrm{L}-1$ for CDK2. ${ }^{38}$

Another compound with similar structure, SU9516, a novel 3-substituted indolinone compound, had effects on colon cancer cell kinase activity, cell proliferation, cell cycle progression, and apoptosis examined. ${ }^{39}$ In this case, the studies aimed at the so called cyclin-dependent kinases (CDK), which are key-regulators of the cell cycle. Protein kinases constitute a large class of proteins that catalyze the phosphorylation of target proteins and enzymes. They can regulate a wide range of processes including carbohydrate and lipid metabolism, neurotransmitter biosynthesis, DNA transcription and replication, organelle trafficking, smooth muscle contraction, and cell differentiation..$^{40}$ These proteins are specific for each phase of the cell cycle, and determine the progression of distinctive and wellordered phosphorylation events occurring. Therefore, they constitute promising target for anticancer drug development. ${ }^{41}$ It was demonstrated that the oxindole
SU9516 is a potent and selective inhibitor of the CDK2 kinase catalytic activity; it also decreases liganddependent and -independent cell cycle progression, and increases apoptosis in a cell line-specific manner.

On the other hand, some oxindole-derivative compounds have been reported as potent inhibitors of vascular endothelial growth factor (VEGF) that stimulated angiogenesis. ${ }^{42}$ Angiogenesis, the development of the microvasculature, is a complex multistep event, described as a crucial aspect of tumor growth and spread. Tumors with greatest vasculature are often associated with poorer prognosis and higher metastatic potential. Angiogenesis inhibitors prevent the growth of blood vessels from surrounding tissue of a solid tumor, and those VEGF exert their effect in tumor growth by binding to cell surface receptors which have intrinsic tyrosinase kinase activity. ${ }^{43}$ The oxindole derivatives named SU5416 and SU6668 (shown in Figure 6) inhibited angiogenesis in vitro by $>86 \%$ at $10 \mu \mathrm{mol} \mathrm{L} \mathrm{L}^{-1}$ concentration, and this inhibition was already significant at $1 \mu \mathrm{mol} \mathrm{L} \mathrm{L}^{-1}$. Both compounds are nowadays in clinical trial for cancer treatment. ${ }^{44}$

Novel oxime-derivatives of indirubin, a metabolite of isatin oxidation and an active ingredient of a traditional Chinese medicine containing a bis-oxindole skeleton (see examples in Figure 7) have been recently developed, based on structure-activity relationship studies, as potent cancer cell growth inhibitors for different cell lines. Recent investigations indicated that these oxindoles display high inhibition of some cyclin-dependent kinases (CDK2). ${ }^{45}$
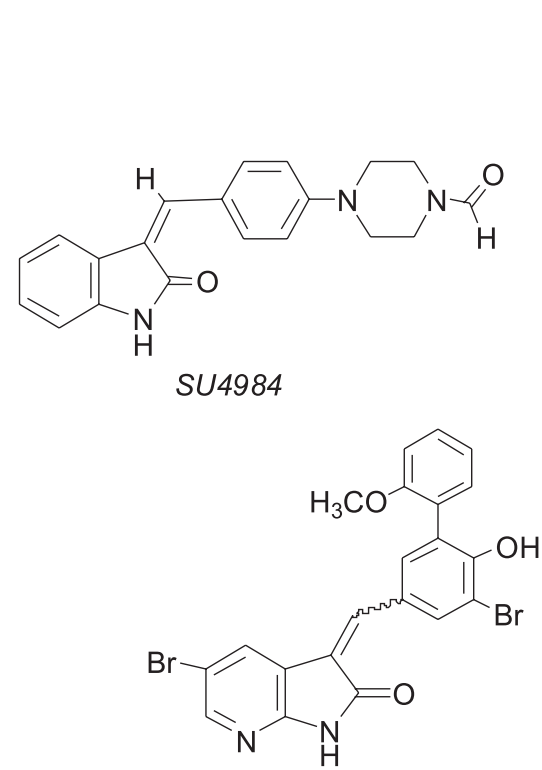

Compound A

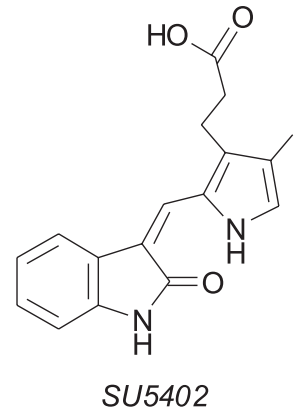<smiles>COc1ccc2c(c1)/C(=C/c1cnc[nH]1)C(=O)N2</smiles>

SU9516<smiles>O=C1Nc2ccccc2/C1=C1\CCc2cc(O)ccc21</smiles>

Compound B

Figure 5. Structure of some synthetic oxindole compounds, inhibitors of tyrosine kinases (PTK) or cyclin-dependent kinases (CDK). 


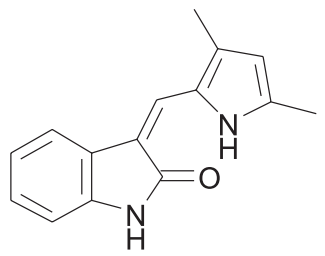

SU5416

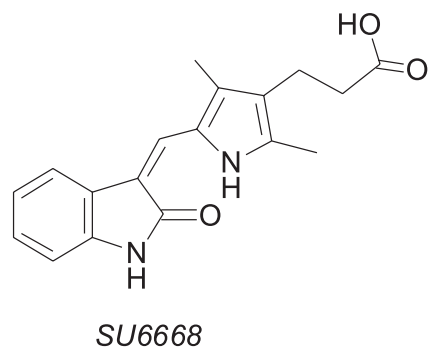

Figure 6. Synthetic oxindoles that can act as anti-angiogenic agents.<smiles>O=C1Nc2ccccc2/C1=C1/Nc2ccccc2C1=O</smiles><smiles>[R]c1cc([R])c2c(c1)/C(=c1\[nH]c3ccc([R])cc3c1=[Z2])C(=O)N2</smiles>

Indirubin

$$
\begin{aligned}
& \mathrm{R}^{1}=\mathrm{H} \\
& \mathrm{R}^{2}=\mathrm{H}, \mathrm{F}, \mathrm{NO}_{2}, \text { or } \mathrm{CF}_{3} \mathrm{O} \\
& \mathrm{R}^{3}=\mathrm{H}, \text { or } \mathrm{CH}_{3} \\
& \mathrm{R}^{4}=\mathrm{NOH}
\end{aligned}
$$

Figure 7. Indirubin and some derivatives with anti-proliferative activity.

\section{Oxindoles as Ligands for Copper and other Metal Ions}

By now, many metal complexes with oxindoles have been described in the literature. The early reports did not reveal biological interest, but as soon as pharmacological activities started to be demonstrated for these compounds, their metal complexes also gained biological relevance, and their antibacterial, antiproliferative or mutagenic properties were also investigated.

Some Schiff bases derived from isatin were prepared by reaction with amino acids or substituted hydrazines and were subsequently metallated with nickel(II), iron(III) or cobalt(II) ions. ${ }^{46}$ Zinc(II) and mercury(II) complexes of isatin-3-thiosemicarbazone were isolated and spectroscopically characterized. ${ }^{47}$ Copper(II), nickel(II) and cobalt(II) complexes with pyridyl- and quinolylhydrazones of isatin and $N$-methylisatin have also been prepared. In the case of the copper complex, spectroscopic results suggested a planar geometry. ${ }^{48}$ Copper(II), chromium(III), manganese(II), cobalt(II), nickel(II), zinc(II), cadmium(II) and lead(II) chelates with tetradentate Schiff base derived from isatin by reaction with $o$-phenylenediamine were also isolated. In this case, the complexes were obtained as neutral species with divalent ions, and in the enolic form of the ligand (see Figure 8). ${ }^{49}$ Similar species of copper(II) were prepared with 1,3-diaminoethane, which subsequently produced binuclear metal complexes by further coordination to another copper(II), uranyl, lanthanium(III) or cerium(III) ion. ${ }^{50}$ On the contrary, some coordination compounds of cobalt(II), nickel(II) and copper(II) with Schiff bases obtained by the condensation of isatin with sulfamethazine or ethazole were isolated in the keto-form of the ligands. Structures of these species are also shown in Figure $8 .^{51}$

The formation constants of ternary compounds, MLL', where $\mathrm{M}=\mathrm{Co}^{\mathrm{II}}, \mathrm{Ni}^{\mathrm{II}}, \mathrm{Cu}^{\mathrm{II}}$ or $\mathrm{Zn}^{\mathrm{II}} ; \mathrm{L}=$ isatin, and $\mathrm{L}^{\prime}=$ amino acids (gly, ala, or val), or 1,2-diaminoethane, or 2,2'bipyridyl, were determined, at $30^{\circ} \mathrm{C}$, in $5 \%$ ethanol-water solutions. The stabilities of these species followed the expected Irving-Williams order: $\mathrm{Co}^{\mathrm{II}}<\mathrm{Ni}^{\mathrm{II}}<\mathrm{Cu}^{\mathrm{II}}>\mathrm{Zn}^{\mathrm{II}}{ }^{52}$

$\mathrm{Co}^{\mathrm{II}}, \mathrm{Ni}^{\mathrm{II}}$ and $\mathrm{Cu}^{\mathrm{II}}$ complexes of thiosemicarbazones, prepared by condensation of isatin or 1-methylisatin with the appropriate $N(4)$-substituted thiosemicarbazide, were studied by different spectral methods. ${ }^{53,54}$ Some of these complexes, as well as the analogous species with $\mathrm{Zn}^{\mathrm{II}}, \mathrm{Cd}^{\mathrm{II}}$, $\mathrm{Pb}^{\mathrm{II}}$ and $\mathrm{Tl}^{\mathrm{I}}$, were also obtained by electrochemical synthesis. ${ }^{55}$ The increasing interest in these metal species, particularly copper, comes from the fact that 3-thiosemicarbazones of isatin were previously found to be active in the treatment of smallpox. The suggested mode of action of these compounds could involve inhibition of virus growth through binding to copper ions, which are constituents of the virus. Additionally, 1-methylisatin-3-thiosemicarbazone copper(II), nickel(II) and cobalt(II) complexes were isolated and had their X-ray crystal structure determined, motivated by the biological activities of this type of proligand. ${ }^{56}$

Complexes of divalent copper, cobalt, nickel and zinc ions with 3-salicylidenehydrazono-2-indolinone were isolated in the keto-form of the ligand, as shown in Figure 9, and exhibited antimicrobial activity against gram-positive and gram-negative organisms. This activity was enhanced compared to the proligand itself, especially against Candida albicans, and decreased in the metal order $\mathrm{Zn} \geq \mathrm{Cu}>\mathrm{Co}>\mathrm{Ni}^{57}$

More recently, a series of organotin(IV) complexes with ligands derived from isatin or $N$-alkylisatin and 


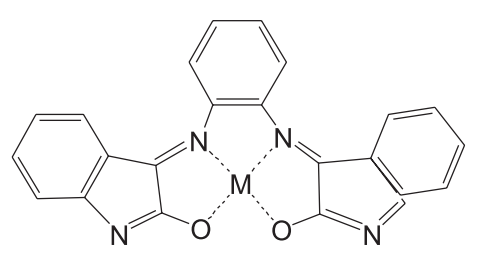

$\mathrm{ML} . \mathrm{nH}_{2} \mathrm{O} \mathrm{n}=1,2,3$ or 4

$\mathrm{M}=\mathrm{Cu}, \mathrm{Co}, \mathrm{Ni}, \mathrm{Zn}, \mathrm{Cd}, \mathrm{Pb}$
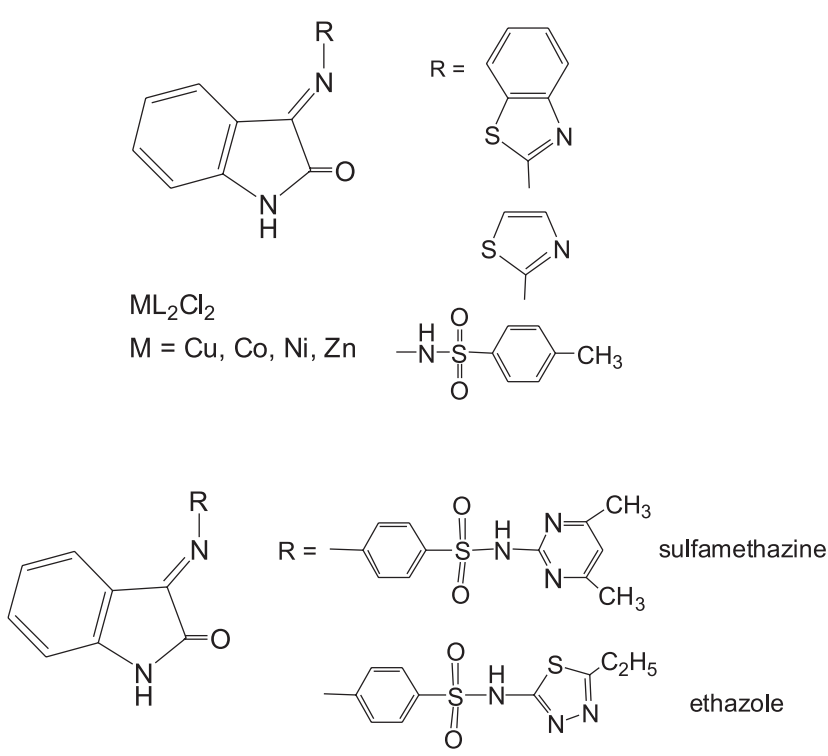

$\mathrm{ML}_{2} \mathrm{X}_{2} \cdot 2 \mathrm{H}_{2} \mathrm{O}$

$\mathrm{M}=\mathrm{Co}, \mathrm{Ni}, \mathrm{Cu}, \mathrm{Zn}$

$\mathrm{X}=\mathrm{Cl}, \mathrm{Br}, \mathrm{NO}_{3}$

Figure 8. Structures of different metal complexes with oxindole-derived ligands.

thiocarbonohydrazones were synthesised, characterized and showed significant antibacterial activity against gram-positive bacteria. $^{58}$

Different isatin-derivatives incorporating thiazole, thiadiazole, benzothiazole and $p$-toluene sulfonylhydrazide moieties were prepared, as well as their corresponding cobalt(II), copper(II), nickel(II) and zinc(II) complexes..$^{59}$ These compounds also showed good results as antibacterial and antifungal agents against different strains, and most of them had their activity enhanced on complexation.

\section{Antitumoral Activity of Copper Complexes}

\subsection{Studies focusing on oxindole-copper(II) complexes}

By now, very few studies have focused on the antiproliferative activity of oxindole-copper complexes, in an attempt to ameliorate the proligand performance in its

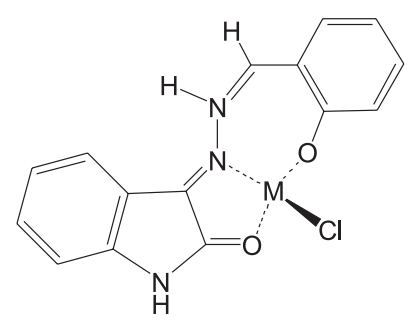

$[\mathrm{M}(\mathrm{L}) \mathrm{Cl}] \mathrm{Cl}$

$\mathrm{L}=$ 3-salicylidenehydrazono-2-indolinone $\mathrm{M}=\mathrm{Co}, \mathrm{Ni}, \mathrm{Cu}, \mathrm{Zn}$

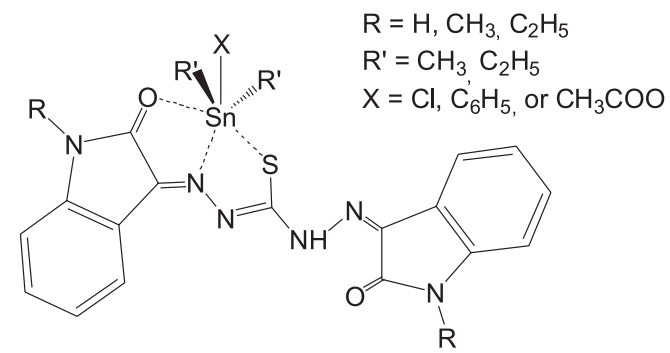

Figure 9. Some hydrazone-indolinone complexes with antibacterial and antifungal activities. 
interaction with biomolecules and aiming at their possible use as antitumoral agents.

Complexes of manganese(II), iron(II), cobalt(II), nickel(II), copper(II), and zinc(II) with isatin- $\beta$-thiosemicarbazone were prepared (see Figure 10), and the nickel complex was structurally characterized by X-ray crystallography. Investigations of cellular growth and apoptosis induction in the presence of these species indicated that the proligand and the corresponding nickel(II) and copper(II) complexes can inhibit cell proliferation of human leukemia U937cell lines. ${ }^{60}$ It was observed that the proligand and its copper complex were equally active, inhibiting the cellular growth by nearly $70 \%$ at $20 \mu \mathrm{g} \mathrm{mL}^{-1}$. With the nickel complex, an inhibition of only $30 \%$ was verified at $10 \mu \mathrm{g} \mathrm{mL}^{-1}$; at higher concentration this complex was cytotoxic. This behaviour of the copper complex was unusual: in previous studies, higher activity has generally been observed for copper complexes in comparison to the proligands. ${ }^{61}$ However, neither the proligand nor the copper complex were able to induce apoptosis as estimated by DNA fragmentation, even after $18 \mathrm{~h}$ of incubation.

Copper(II), nickel(II) and zinc(II) isatin-hydrazone complexes had their potential activity as antitumor agents evaluated on diverse human leukemic cells. ${ }^{62}$ They inhibited the S-phase of TOM1 cell proliferation by $c a$. $40 \%$, but there was no effect observed on other tumoral cell lines. From these studies, it is clear that some copper complexes can specifically interfere with the cell cycle at different levels, but the mechanism behind their way of action is far from being elucidated.

Copper(II) complexes with oxindolimine ligands, obtained by condensation of isatin with different amines, were recently prepared and spectroscopically characterized in our laboratory. ${ }^{63}$ The reactivity of these complexes towards different biomolecules was then extensive and systematically studied. These complexes exhibited keto-enol equilibria, similar to the proligand, being some of them isolated as the keto-form, and others as the corresponding enolic-form, as shown in Figure 11. Their catalytic activity towards the oxidation of common carbohydrates (glucose, fructose and galactose) was verified, and indicated a significant initial rate increase,

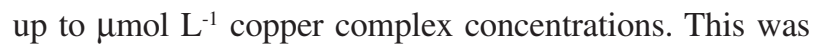
the first report indicating a dependence of catalyzed carbohydrate oxidation rate on metal concentration. A modulation of the copper ion reactivity by the oxindolimine ligand was also observed, and this oxidationpromoting activity was verified to occur via generation of reactive oxygen species, especially hydroxyl radical. ${ }^{64}$ Former studies in the literature have been carried out with much higher copper concentrations, in the mmolar range, and in the presence of very poor coordinating ligands. As a consequence, the verified kinetic law indicated a zeroorder on the metal.

These oxindolimine-copper(II) complexes also showed a relatively high stability, tested toward the ligand substitution in competitive equilibria with albumin, monitored by $\mathrm{CD}$ spectra. ${ }^{65}$ The estimated stability constants, $\log \mathrm{K}_{\mathrm{CuL}}=15-16$, were very similar to that reported for copper-albumin, $\log \mathrm{K}_{\mathrm{Cu}(\mathrm{BSA})}=16.2$, and those already observed for other di-imine copper(II) complexes. ${ }^{66}$

Further investigations on the effects of these oxindolimine-copper(II) complexes on cell viability indicated that some of them can significantly induce the apoptotic program in human promonocytic U937 and human neuroblastoma SH-SY5Y cells. ${ }^{67}$ This activity was shown to be dependent on cell line and also on the ligand. Compound 3 (see Figure 11) was the most effective in inducing the $\mathrm{G}_{2} / \mathrm{M}$ phase arrest in SH-SY5Y cells, after $24 \mathrm{~h}$ of treatment. On the other hand, compound $\mathbf{1}$ seemed to act at $\mathrm{G}_{1}$ phase, and a significant increase in apoptotic population became evident after $48 \mathrm{~h}$. Additionally they exhibited a noteworthy capability of generating reactive oxygen species, especially hydroxyl radical, also modulated by the ligand. Further studies are presently in development in our laboratory, and the new results suggested different mechanisms of action for the most active complexes in this series. ${ }^{68}$ The main biological target in this case seems to be the
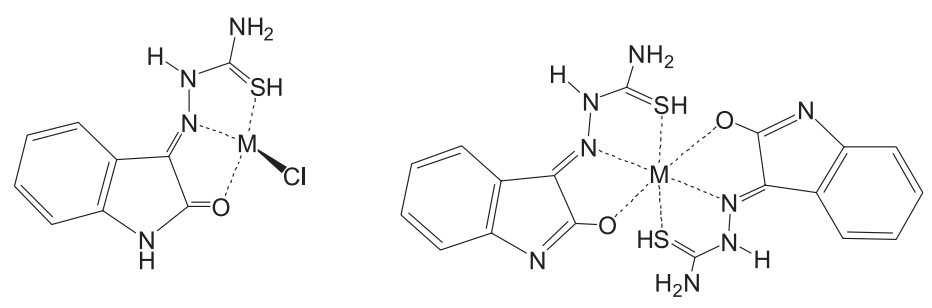

$\mathrm{M}\left(\mathrm{H}_{2} \mathrm{~L}\right)_{2} \mathrm{Cl}_{2} ; \mathrm{M}=\mathrm{Co}, \mathrm{Ni}, \mathrm{Mn}, \mathrm{Fe}$
$\mathrm{M}(\mathrm{HL})_{2} ; \mathrm{M}=\mathrm{Cu}, \mathrm{Zn}, \mathrm{Ni}$
or $\mathrm{M}\left(\mathrm{H}_{2} \mathrm{~L}\right) \mathrm{Cl} ; \mathrm{M}=\mathrm{Cu}$

Figure 10. Selective examples of isatin- $\beta$-thiosemicarbazone complexes active in the inhibition of cell proliferation. 
mitochondria, since an exacerbated consumption of oxygen was observed in the presence of the copper complexes. ${ }^{69}$

\subsection{Selected studies of copper complexes with other ligands}

Besides oxindoles, different Lewis bases coordinated to copper(II) ions have their biological activities enhanced, and some of them have been already studied as potential cancer chemotherapeutic agents. ${ }^{70}$

A large number of bis(thiosemicarbazones) and several of their copper complexes were among the earlier studied compounds. The 3-ethoxy-2-oxobutyraldehyde bis(thiosemicarbazone) or $\mathrm{H}_{2} \mathrm{KTS}$, and related ligands, were all inactive towards antitumoral activity against Walker 256 rat tumor cells. However, in the presence of copper ions at a level of $0.4 \mu \mathrm{g} \mathrm{mL}^{-1}$, all the chelates formed in situ were highly active. When pre-formed complexes were tested, only the copper and zinc complexes showed appreciable activity. Further studies on iron and copper complexes with 5-substituted 2-formylpyridine thiosemicarbazones indicated significant inhibition of Ehrlich ascites tumor cells growth, in the presence of these complexes. ${ }^{71}$

Particularly, thiosemicarbazones, hydrazones, and analogous compounds, as well as their copper complexes, have been intensively studied as inducing agents of apoptosis, in spite of showing low efficiency in many cases. The biological effects of these complexes are supposed to be related to weak interactions with DNA. Some new thiosemicarbazones derived from salicylaldehyde or methylpiruvate have been synthesized, and the corresponding copper(II) and zinc(II) complexes isolated. ${ }^{72}$ The ligand helicin thiosemicarbazone scarcely inhibited U937 cell proliferation, and the analogous copper thiosemicarbazone complex showed $40 \%$ inhibition. However, both compounds were not able to cause DNA fragmentation, inducing apoptosis. Also, studies on new copper complexes with 5-formyluracil thiosemicarbazones derivatives were carried out. In spite of these species being able to interact with DNA by electrostatic or groove

A)

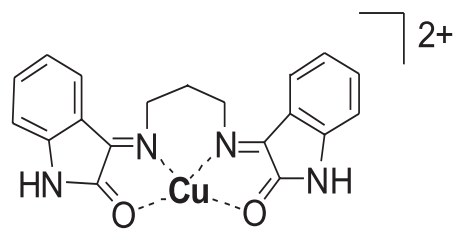

1

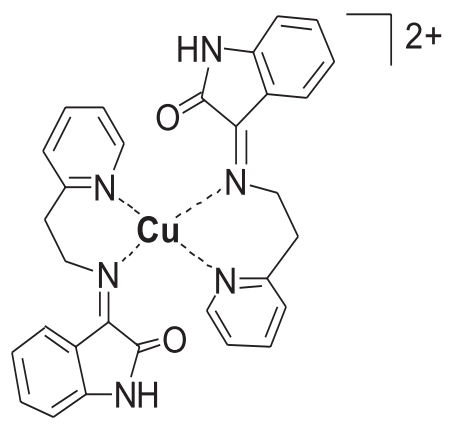

3

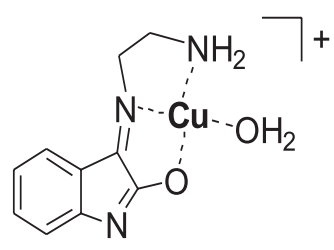

2

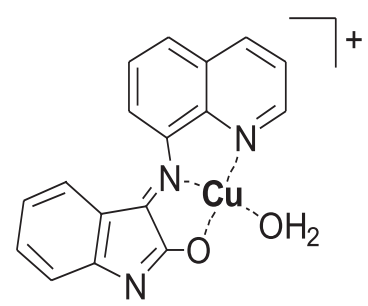

4

B)

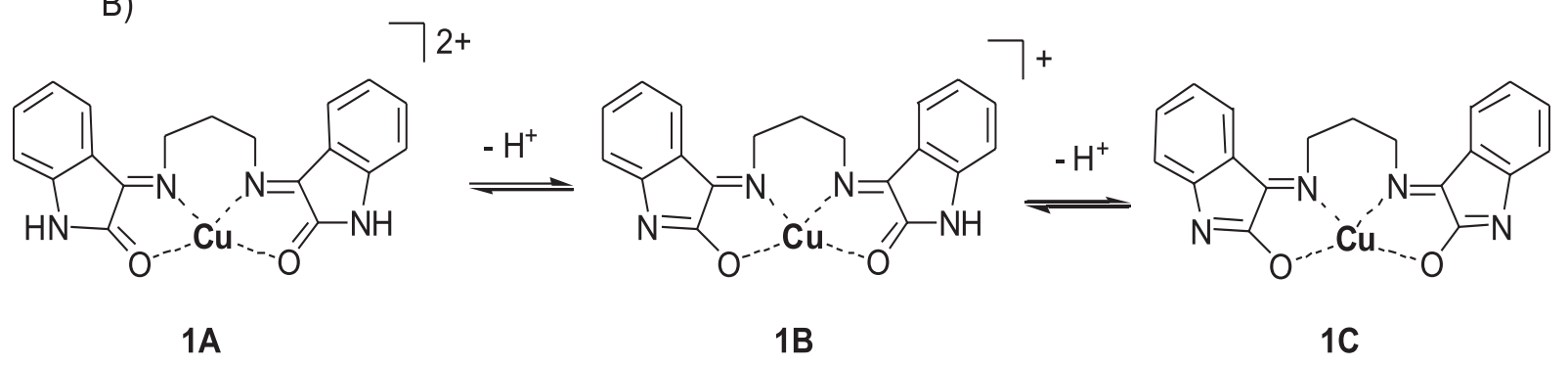

Figure 11. A) Examples of oxindolimine-copper(II) complexes capable of inducing apoptosis; B) Keto-enolic equilibria in a copper(II) complex with an oxindolimine ligand. 
binding, but not by intercalation, neither the proligands nor the metal complexes interfered with cell proliferation of leukemic cells. ${ }^{73}$ Structures of some copper complexes with this type of ligand are shown in Figure 12.

On the other hand, two new copper pyridoxal thiosemicarbazone complexes with nitroprusside, $\left[\mathrm{Fe}(\mathrm{CN})_{5} \mathrm{NO}\right]$, as counterion were found to be active in inhibiting leukemic cell proliferation (monoblastoid U937 and lymphoblastoid CEM lines) and in inducing apoptosis. The cells were arrested at the $\mathrm{G}_{2} / \mathrm{M}$ phase, in a dose- and time-dependent action. ${ }^{74}$ According to these studies, the nitroprusside seemed to have no cooperative effect.

The copper(1,10-phenanthroline) complex has been extensively studied as capable of inducing apoptosis, since it showed nuclease activity in the presence of reducing agents and molecular oxygen, by redoxcycling and stimulation of reactive oxygen species (ROS) formation. ${ }^{75}$ This complex induced $\mathrm{G}_{1}$-phase specific apoptosis in liver carcinoma Bel-7402 cell line. ${ }^{76}$ More recent studies, focusing on the mechanism of this complex cytotoxicity, showed that an abnormal elevation of intracellular copper, which is transported by the lypophylic phenanthroline ligand, plays a crucial role in the initiation of apoptotic process, with increased ROS production and decreased GSH/GSSG ratio. ${ }^{77}$ Further, this same complex exhibited potent cytotoxicity against human leukemic HL-60 cells and human stomachal SGC-7901 cells, with growth inhibition up to $90 \% .^{78}$

Ternary copper complexes with the scorpionate ligand dihydrobis(3-nitro-1,2,4,-triazolyl)borate (see Figure 13), and phosphane as co-ligand had their cytotoxicity tested against several human tumor cells lines, and showed appreciable activity with $\mathrm{IC}_{50}$ lower than those exhibited by cisplatin, the most studied metal-based antitumor drug. Also, they were particularly effective against A549 carcinoma cells that are resistant to cisplatin treatment. ${ }^{79}$

Very recently, the sulfur and nitrogen donor ligand, N'-[(2-hydroxyphenyl)carbonothioyl]pyridine-2-carbohydrazide (Figure 13) and its copper(II) and manganese(III) complexes were also shown to be toxic against colon cancer HT29 cell line. ${ }^{80}$ The cells treated with these metal complexes induced apoptosis and inhibited endogenous $\mathrm{N}$-myristoyltransferase activity, which was suggested to be crucial for cell survival.

Finally, triazole-type ligands coordinated to copper ions have also been evaluated as antiproliferative agents. The complexes with unsymmetrical 4-amino-1,2,4triazoles (see Figure 13) exhibited a tetragonally distorted octahedral coordination around copper and were active against different HT-type adenocarcinoma cells. ${ }^{81}$ However, the observed antiproliferative activity of these complexes was similar to that of copper chloride, suggesting that this activity may be ascribed to species formed with bioligands in the culture medium. Also, for all cell lines tested, the copper complexes had very low activity if compared to cisplatin.

\section{Copper and Apoptosis}

In the traditional cancer chemotherapy, many drugs exert their cytotoxic effects by inducing apoptosis, and novel propositions focus on drugs that modulate<smiles>[R]NC1=NN2C([R])C([R])=NN2[CH]S1</smiles><smiles></smiles>

$\mathrm{R}^{1}=\mathrm{CH}_{3}, \mathrm{CH}_{3} \mathrm{OCH}\left(\mathrm{CH}_{3}\right), \mathrm{C}_{2} \mathrm{H}_{5} \mathrm{OCH}\left(\mathrm{CH}_{3}\right)$

$\mathrm{R}=\mathrm{H}, \mathrm{OH}, \mathrm{Cl}, \mathrm{OCOCH}_{3}, \mathrm{CH}_{3}$, or $\mathrm{CF}_{3}$ $\mathrm{R}^{2}=\mathrm{H}$, or $\mathrm{CH}_{3}$

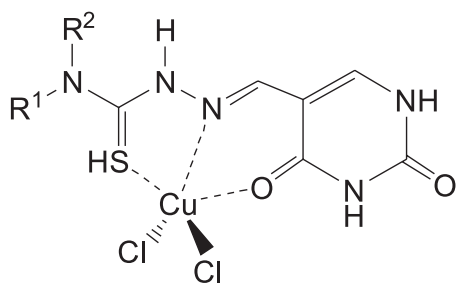

$\mathrm{R}^{1}, \mathrm{R}^{2}=\mathrm{H}$, or $\mathrm{CH}_{3}$

Figure 12. Some thiosemicarbazone-copper complexes with antiproliferative activity. 
apoptosis, named as "apoptosis-modulating drugs". ${ }^{82}$ Most of the copper complexes of interest were shown to induce apoptosis, although some of them only inhibited cell proliferation, but were not able of inducing the apoptotic process.

Apoptosis has a major role in some physiological processes, and it is also a fundamental process active in numerous pathological events, such as sepsis, neurodegenerative diseases and cancer. ${ }^{83}$ Apoptotic cell death can occur by two distinct pathways: a liganddependent activation of cell surface receptors, or activation of the mitochondrial death pathway. Since significant crosstalk occurs between these two processes the overall apoptotic response can be amplified. If the integrity of the outer membrane in cells is lost, apoptotic proteins are released into the citosol, and they can activate the so called caspases, proteins of the cysteine protease family, or act in a caspase-independent way to induce cell death. ${ }^{84}$ Caspase-dependent factors include, for example, cytochrome c, while caspase-independent factors comprise endonuclease $\mathrm{G}$ (endo $\mathrm{G}$ ), and apoptosis inducing factor (AIF). Additionally, based on the observation that most conventional and experimental chemotherapeutic agents promote the permeabilization of mitochondrial membranes in cancerous cells, the mitochondria have also emerged as a novel target for anticancer therapy. ${ }^{85}$

Since cyclin-dependent kinases have a crucial role in the apoptotic process, many studies use the approach of targeting these proteins through the development of diverse inhibitors. ${ }^{86,87}$ Among those inhibitors, oxindole derivatives have received substantial attention. Further, as antagonists of receptor tyrosinase kinases, oxindole derivatives are also attracting increasing interest. ${ }^{88}$ Growth factor receptors exhibiting a tyrosinase kinase activity are proteins involved in a wide variety of cellular functions, and in many cell types they drive growth, differentiation and angiogenesis, by transducing growth factor signals from the external environment to intracellular processes. Alterations in tyrosinase kinase receptor pathways have been also implicated in oncogenic activation and tumor angiogenesis. There is evidence that the mechanism for activation of these proteins (PTK) has steps under redox-control. ${ }^{89}$ Therefore, as small molecules that can interact with a wide range of enzymes implicated in the cellular functions, oxindoles are envisaged as promising cancer chemotherapeutical agents.

On the other hand, redox regulation is evolving as a new challenge for pharmacology. ${ }^{90}$ The focus is to develop drugs capable of modulating the oxidative trigger mechanisms or enforcing reductive pathways in cells. ${ }^{91}$ Persistent oxidative events, in addition to a decline in the cellular reduction potential, accompanied by substantial oxygen radical induced damage, seems to be involved in most of the major degenerative diseases. Redox regulation, on the contrary, involves subtle and chemically defined oxidations of short duration, based on the existence of a redox-based network of regulatory mechanisms, intimately linked to cellular functions.

Particularly, copper-dependent toxicity in tumoral cells seems to be linked to mitochondrial dysfunction ${ }^{92}$ involving the production of reactive oxygen species, which is amplified in the presence of reducing agents, and

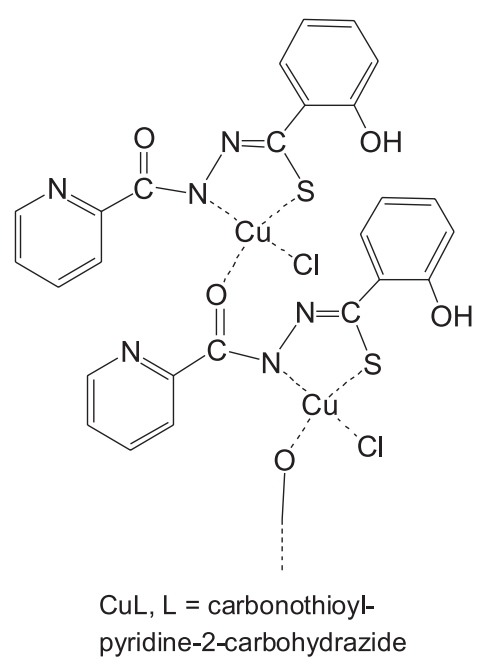<smiles></smiles><smiles></smiles>

$\operatorname{CuL}\left(\mathrm{PR}_{3}\right)_{2}, \mathrm{~L}=$ dihydrobis(3-nitro-1,2,4triazol-1-yl)borate; $\mathrm{R}=(p$-tolyl) phosphane

Figure 13. Other selected copper complexes with antiproliferative activity. 
decreasing the levels of several mitochondrial proteins. Therefore, specific ligands for copper, capable of modifying and modulating its reactivity and of targeting active proteins in the cellular proliferation and regulation of apoptotic pathways are certainly serious candidates for the hole of pharmacological agents.

In this context, oxindole-derivatives are a subclass of copper chelators with antitumoral activity deserving further development as promising components of metalbased drugs. A better understanding of the molecular mechanisms by which such compounds act can provide a theoretical basis for new clinical approaches in anticancer therapies.

\section{Acknowledgments}

The authors thank FAPESP (Projects 01/09127-6 and 05/60596-8), and CNPq (Redoxoma Milenium Project) for financial support. G.C. also thanks FAPESP and CAPES for a Ph.D. fellowship.

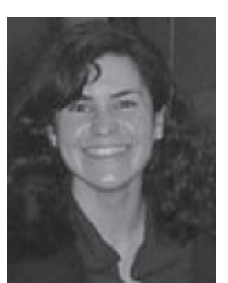

Giselle Cerchiaro obtained a M.S. degree from Unicamp (1997), and a Ph.D. degree in Chemistry from the Universidade de São Paulo (2005). She worked on the reactivity of copper complexes and bioinorganic chemistry, under the supervision of Professor Ana M.D.C. Ferreira, and also spent some time at Università Tor Vergata di Roma. She has been a Pos-Doc in the laboratory of Professor Ohara Augusto at USP in 2005/ 2006, working on free radicals reactivity in chemistry and biology. Presently, she has a new post as associate professor at the Universidade Federal do ABC, in Santo Andre, Brazil.

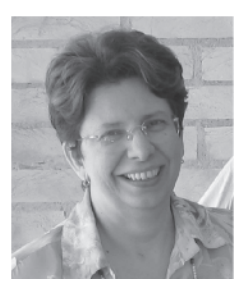

Ana Maria da Costa Ferreira is a Professor of Inorganic Chemistry in the Instituto de Química, Universidade de São Paulo, Brazil. Her research interests are focused on catalytic and biological activities of transition metal compounds, including its syntheses, characterization by structural, spectroscopic and magnetic properties, studies on kinetics and mechanisms of reaction, detection and identification of reactive species as intermediates in oxidative processes. More recently, she has been developing applications of metal complexes as antitumoral agents, or new oxidation catalysts.

\section{References}

1. Orvig, C.; Abrams, M. J.; Chem. Rev. 1999, 99, 2201; Thompson, K. H.; Orvig, C.; J. Chem. Soc., Dalton Trans. 2006, 761; Farrell, N.; Coord. Chem. Rev. 2002, 232, 1; Abrams, M. J.; Murrer, B. A.; Science 1993, 261, 725.

2. Timerbaev, A. R.; Hartinger, C. G.; Aleksenko, S. S.; Keppler, B. K.; Chem. Rev. 2006, 106, 2224.

3. Ming, L. J.; Med. Res. Rev. 2003, 23, 697.

4. Louie, A. Y.; Meade, T. J.; Chem. Rev. 1999, 99, 2734; Guo, Z.; Sadler, P. J.; Angew. Chem., Int. Ed. 1999, 38, 1512.

5. Ming, L. J.; Epperson, J. D.; J. Inorg. Biochem. 2002, 91, 46; Kratz, F.; Schutte, M. T.; Cancer J. 1998, 11, 176; BernersPrice, S. J.; Sadler, P. J.; Coord. Chem. Rev. 1996, 151, 1.

6. Wang, M. Z.; Meng, Z. X.; Liu, B. L.; Cai, G. L.; Zhang, C. L.; Wang, X. Y.; Inorg. Chem. Commun. 2005, 8, 368; MarinHernandez, A.; Gracia-Mora, I.; Ruiz-Ramirez, L.; MorenoSanchez, R.; Biochem. Pharmacol. 2003, 65, 1979; Lewis, J. S.; Laforest, R.; Buettner, T. L.; Song, S. K.; Fujibayashi, Y.; Connett, J. M.; Welch, M. J.; Proc. Natl. Acad. Sci. U.S.A. 2001, 98, 1206; Henke, S. L.; Expert Opin. Ther. Pat. 1999, 9, 169.

7. Huang, R.; Wallqvist, A.; Covell, D. G.; Biochem. Pharmacol. 2005, 69, 1009.

8. See for example: Kang, J.; Chen, J.; Shi, Y.; Jia, J.; Wang, Z.; J. Biol. Inorg. Chem. 2005, 10, 190; Zhao, R.; Planalp, R. P.; Ma, R.; Greene, B. T.; Jones, B. T.; Brechbiel, M. W.; Torti, F. M.; Torti, S. V.; Biochem. Pharmacol. 2004, 67, 1677; Yoshino, M.; Haneda, M.; Naruse, M.; Htay, H. H.; Tsubouchi, R.; Qiao, S. L.; Li, W. H.; Murakami, K.; Yokochi, T.; Toxicol. In Vitro 2004, 18, 783.

9. Rossi, L.; Aquilano, K.; Filomeni, G.; Lombardo, M.F.; Rotilio, G.; Ciriolo, M.R.; Frontiers in Neurodegenerative Disorders and Aging: Fundamental Aspects, Clinical Perspectives and New Insights, T. Özben and M. Chevion, eds., IOS Press, NATO Science Series, Amsterdam, The Netherlands, 2004, p. 207-250.

10. Linder, M. C.; Mutat. Res. 2001, 475, 141.

11. Kaim, W.; Rall, J.; Angew. Chem., Int. Ed. 1996, 35, 43; Solomon, E. I.; Chen, P.; Metz, M.; Lee, S. K.; Palmer, A. E.; Angew. Chem., Int. Ed. 2001, 40, 4570; Mirica, L. V.; Ottenwaelder, X.; Stack, T. D. P.; Chem. Rev. 2004, 104, 1013; Kim, E.; Chufan, E. E.; Kamaraj, K.; Karlin, K. D.; Chem. Rev. 2004, 104,1077.

12. Fridovich, I.; J. Exp. Biol. 1998, 201, 1203; Rotilio, G.; Carrí, M. T.; Rossi, L.; Ciriolo, M. R.; IUBMB Life 2000, 50, 309; Letelier, M. E.; Lepe, A. M.; Fáundez, M.; Salazar, J.; Marín, R.; Aracena, P.; Speisky, H.; Chem.-Biol. Interact. 2005, 151, 71.

13. Rosenzweig, A. C.; Acc. Chem. Res. 2001, 34, 119; Falconi, M.; Iovino, M.; Desideri, A.; Structure 1999, 7, 903.

14. Rosenzweig, A. C.; O’Halloran, T. V.; Curr. Opin. Chem. Biol. 2000, 4, 140; O'Halloran, T. V.; Cullota,V. C.; J. Biol. Chem. 2000, 275, 25057. 
15. Rae, T. D.; Smidt, P. J.; Pufahl, R. A.; Cullota,V. C.; O'Halloran, T. V.; Science 1999, 284, 805.

16. Luk, E.; Jensen, L. T.; Culotta, V. C.; J. Biol. Inorg. Chem. 2003, 8, 803 .

17. Silva, J. F. M.; Garden, S. J.; Pinto, A. C.; J. Braz. Chem. Soc. 2001, 12, 273.

18. Laurent, A.; J. Prakt. Chem. 1842, 25, 430, cited in: Sumpter, W. C.; Chem. Rev. 1944, 34, 393.

19. Baeyer, A.; Ber. 1883, 16, 2188; ibidem, 1882, 15, 2093.

20. Bergman, J.; Lindstrom, J.; Tilstam, U.; Tetrahedron 1985, 41, 2879; Kapadia, G.J.; Shukla, Y. N.; Basak, S. P.; Tetrahedron 1980, 36, 2441

21. Mendvedev, A. E.; Clow, A.; Sandler, M.; Glover, V.; Biochem. Pharmacol. 1996, 52, 385.

22. Usami, N.; Kitahara, K.; Ishikura, S.; Nagano, M.; Sakai, S.; Hara, A.; Eur. J. Biochem. 2001, 268, 5755.

23. Tozawa, Y.; Ueki, A.; Manabe, S.; Matsushima, K.; Biochem. Pharmacol. 1998, 56, 1041; Morley, J. E.; Farr, S. A.; Flood, J. F.; Eur. J. Pharmacol. 1996, 305, 23.

24. Medvedev, A.; Sandler, M.; Glover, V.; Life Sci. 1998, 62, 2391; Glover, V.; Medvedev, A.; Sandler, M.; Life Sci. 1995, 57, 2073

25. Mendvedev, A. E.; Glover, V.; Neuro Toxicol. 2004, 25, 185; Crumeyrolle-Arias, M.; Tournaire, M. C.; Cane, A.; Launay, J. M.; Barrictault, D.; Medvedev, A.; Biochem. Pharmacol. 2004, 67, 977; Mendvedev, A. E.; Goodwin, B.; Clow, A.; Halket. J.; Glover, V.; Sandler, M.; Biochem. Pharmacol. 1992, 44, 590.

26. Verma , M.; Pandeya, S. N.; Singh, K. N.; Stables, J. P.; Acta Pharm. 2004, 54, 49.

27. Sridhar, S. K; Pandeya, S. N.; Stables, J. P.; Ramesh, A.; Eur. J. Pharm. Sci. 2002, 16, 129.

28. Pandeya, S. N.; Sriram, D.; Nath, G.; DeClercq, E.; Eur. J. Pharm. Sci. 1999, 9, 25.

29. Cane, A.; Tournaire, M. C.; Barritault, D.; Crumeyrolle-Arias, M.; Biochem. Biophys. Res. Commun. 2000, 276, 379.

30. Karali, N.; Eur. J. Med. Chem. 2002, 37, 909.

31. Abele, A.; Abele, R.; Dzenitis, O., Lukevics, E.; Chem. Heterocycl. Comp. 2003, 39, 3.

32. Jensen, B. S.; Jorgensen, T. D.; Ahring, P. K.; Christophersen, P.; Strobaek, D.; Teuber, L.; Olensen, S. P.; PCT Int. Appl. WO 0033834 2000. (CA 133, 43434).

33. Najer, H.; Obitz, D.; Kaplan, J. P.; French Patent 25067641983 (CA 99, 38360).

34. Zhou, L.; Liu, Y.; Zhang, W.; Wei, P.; Huang, .; Pei, J.; Yuan, Y.; Lai, L.; J. Med. Chem. 2006, in press; Webber, S. E.; Tikhe, J.; Worland, S. T.; Fuhrman, S. A.; Hendrickson, T. F.; Matthews, D. A.; Love, R. A.; Patick, A. K.; Meador, J. W.; Ferre, R. A.; Brown, E. L.; DeLisle, D. M.; Ford, C. E.; Binford, S. L.; J. Med. Chem. 1996, 39, 507.

35. Jiang, T.; Kuhen, K. L.; Wolff, K.; Yin, H.; Bieza, K.; Caldwell, J.; Bursulaya, B.; Wu, T. Y. H.; He, Y.; Bioorg. Med. Chem. 2006, 16, 2105
36. Mohammadi, M.; McMahon, G.; Sun, L.; Tabg, C.; Hirth, P.; Yeh, B. K.; Hubbard, S. R.; Schlessinger, J.; Science 1997, 276, 955;

37. Levitzki, A.; Gazit, A.; Science 1995, 267, 1782.

38. Wood, E. R.; Kuyper, L.; Petrov, K. G.; Hunter III, R. N.; Harris, P. A..; Lackey, K.; Bioorg. Med. Chem. 2004, 14, 953.

39. Lane, M. E.; Yu, B.; Rice, A.; Lipson, K. E.; Liang, C.; Sun, L.; Tang, C.; MacMahon, G.; Pestell R. G.; Wadler, S.; Cancer Res. 2001, 61, 6170.

40. Adams, J. A.; Chem. Rev. 2001, 101, 2271; Harper, J. W.; Adams, P. D.; Chem. Rev. 2001, 101, 2511.

41. Golsteyn, R. M.; Cancer Lett. 2005, 217, 129; Benson, C.; Kaye, S.; Workman, P.; Garrett, M.; Walton, M.; Bono, J.; Br. J. Cancer 2005, 92, 7 .

42. Whatmore, J. L.; Swann, E.; Barraja, P.; Newsome, J. J.; Bunderson, M.; Beall, H. D.; Tooke, J. E.; Moody, C. J.; Angiogenesis 2002, 5, 45.

43. Kerbel, R. S.; Carcinogenesis 2000, 21, 505.

44. http://www.cancer.gov/clinical_trials, accessed in June 7, 2006.

45. Moon, M. J.; Lee, S. K.; Lee, J. W.; Song, W. K.; Kim, S. W.; Kim, J. I.; Cho, C.; Choi, S. J.; Kim, Y. C.; Bioorg. Med. Chem. 2006, 14, 237.

46. Hassaan, A. M. A.; Transition Met. Chem. 1990, 15, 283; Hassaan, A. M. A.; J. Islamic Acad. Sci. 1991, 4, 271.

47. Akinchan, N. T.; Drozdzewski, P. M.; Holzer, W.; J. Mol. Struct. 2002, 641, 17.

48. Khulbe, R. C.; Singh, R. P.; Transition Met. Chem. 1983, 8, 59; Khulbe, R. C.; Bhoon, Y. K.; Singh, R. P.; J. Indian Chem. Soc. 1981, 58,840 .

49. Hassaan, A. M. A.; Khalifa, M. A.; Monatsch. Chem. 1993, 124,803

50. Hassaan, A. M. A.; Al-Nasr, A. K. A.; Khalifa, M. A.; Russ. Coord. Chem. 1997, 23, 356.

51. Tsapkov, V. I.;Al'-Nabgali, N.; Stan, V. V.; Samus, N. M.; Russ. J. Gen. Chem. 1994, 64, 1604.

52. Reddy, C. V. R.; Reddy, M. G. R.; J. Chem. Eng. Data 1994, $39,723$.

53. West, D. X.; El-Sawaf, A. K.; Bain, G. A.; Transition Met. Chem. 1998, 23, 1.

54. Bain, G. A.; West, D. X.; Krejci, J.; Valdés-Martínez, J.; Hernández-Ortega, S.; Toscano, R. A.; Polyhedron 1997, 16, 855.

55. Labisbal, E.; Sousa, A.; Castineiras, A.; García-Vazquez, J. A.; Romero, J.; West, D. X.; Polyhedron 2000, 19, 1255.

56. Ferrari, M. B.; Pelizzi, C.; Pelosi, G.; Rodríguez-Argüelles, M. C.; Polyhedron 2002, 21, 2593.

57. Konstantinovic, S. S.; Radovanovic, B. C.; Cakic, Z.; Vasic, V.; J. Serb. Chem. Soc. 2003, 68, 641.

58. Bacchi, A.; Carcelli, M.; Pelagatti, P.; Pelizzi, G.; RodriguezArguelles, M. C.; Rogolino, D.; Solinas, C.; Zani, F.; J. Inorg. Biochem. 2005, 99, 397. 
59. Chohan, Z. H.; Pervez, H.; Rauf, A.; Khan, K. M.; Supuran, C. T.; J. Enz. Inhib. Med. Chem. 2004, 19, 417.

60. Rodríguez-Argüelles, M. C.; Sanchez, A.; Ferrari, M. B.; Fava, G. G.; Pelizzi, C.; Pelosi, G.; Albertini, R.; Lunghi, P.; Pinelli, S.; J. Inorg. Biochem. 1999, 73, 7.

61. Ferrari, M. B.; Fava, G. G.; Tarasconi, P.; Albertini, R.; Pinelli, S.; Starcich, R.; J. Inorg. Biochem. 1994, 53, 13.

62. Rodrigues-Arguelles, M. C.; Ferrari, M. B.; Bisceglie, F.; Pelizzi, C.; Pelosi, G.; Pinelli, S.; Sassi, M.; J. Inorg. Biochem. 2004, 98, 313.

63. Cerchiaro, G.; Saboya, P. L.; Tomazela, D. M.; Eberlin, M. N.; Ferreira, A. M. D. C.; Transition Met. Chem. 2004, 29, 495.

64. Cerchiaro, G.; Micke, G. A.; Tavares, M. F. M.; Ferreira, A. M. D. C.; J. Mol. Catal. A:Chem. 2004, 221, 29.

65. Santos, M. L. P.; Faljoni-Alario, A.; Mangrich, A. S.; Ferreira, A. M. D.; J. Inorg. Biochem. 1998, 71, 71.

66. Santos, M. L. P.; Bagatin, I. A.; Ferreira, A. M. D.; J. Chem. Soc., Dalton Trans. 2001, 838.

67. Cerchiaro, G.; Aquilano, K.; Filomeni, G.; Rotilio, G.; Ciriolo, M. R.; Ferreira, A. M. D. C.; J. Inorg. Biochem. 2005, 99, 1433.

68. Ferreira, A. M. D. C.; Cerchiaro, G.; Ciriolo, M. R.; Abbott, M. P.; Silveira, V. C.; BR PI 0.600.985-9, 2006.

69. Filomeni, G.; Cerchiaro, G.; Ferreira, A. M. D. C.; De Martino, A.; Pedersen, J. Z.; Rotilio, G.; Ciriolo, M. R.; Personal Communication.

70. Gonzalez-Vílchez, F.; Vilaplana, R.; Chemotherapeutic Copper Compounds, In: Metallotherapeutic Drugs and Metal-based Diagnostic Agents, Gielen, M; Tiekink, E.R.T., eds., J. Wiley, Chichester, England, 2005, chap. 12, p. 219.

71. Van Giessen, G. J.; Petering, H. G.; J. Med. Chem. 1968, 11, 695; Antholine, W. E.; Knight, J. M.; Petering, H. G.; J. Med. Chem. 1976, 19, 339.

72. Ferrari, M. B.; Capacchi, S.; Pelosi, G.; Reffo, G.; Tarasconi, P.; Albertini, R.; Pinelli, S.; Lunghi, L.; Inorg. Chim. Acta 1999, 286, 134; Ferrari, M. B.; Bisceglie, F.; Pelosi, G.; Tarasconi, P.; Albertini, R.; Pinelli, S.; J. Inorg. Biochem. 2001, 87, 137.

73. Baldini, M.; Ferrari, M. B.; Bisceglie, F.; Pelosi, G.; Pinelli, S.; Tarasconi, P.; Inorg. Chem. 2003, 42, 2049.

74. Belicchi-Ferrari, M.; Bisceglie, F.; Casoli, C.; Durot, S.; Morgenstern-Badarau, I.; Pelosi, G.; Pilotti, E.; Pinelli. S.; Tarasconi, P.; J. Med. Chem. 2005, 48, 1671; Ferrari, M. B.;
Bisceglie, F.; Pelosi, G.; Tarasconi, P.; Albertini, R.; Dall'Aglio, P. P.; Pinelli, S.; Bergamo, A.; Sava, G.; J. Inorg. Biochem. 2004, 98, 301.

75. Coyle, B.; Kinsella, P.; McCann, M.; Devereux, M.; O'Connor, R.; Clynes, M.; Kavanagh, K.; Toxicol. in Vitro 2004, 18, 63.

76. Zhou, H.; Zheng, C.; Zou, G.; Tao, D.; Gong, J.; Int. J. Biochem. Cell Biol. 2002, 34, 678.

77. Cai, X.; Pan, N.; Zou, G.; Biometals (Springer), 2006, in press.

78. Zhang, S. C.; Zhu, Y. G.; Tu, C.; Wei, H. Y.; Yang, Z.; Lin, L. P.; Ding, J.; Zhang, J. F.; Guo, Z. J.; J. Inorg. Biochem. 2004, 98, 2099.

79. Marzano, C.; Pellei, M.; Alidori, S.; Brossa, A.; Lobbia, G. G.; Tisato, F.; Santini, C.; J. Inorg. Biochem. 2006, 100, 299.

80. Shrivastav, A.; Singh, N. K.; Tripathi, P.; George, T.; Dimmock, J. R.; Sharma, R. K.; Biochemie (Elsevier), 2006, in press.

81. Gaccioli, F.; Franchi-Gazzola, R.; Lanfranchi, M.; Marchiò, L.; Metta, G.; Pellinghelli, M. A.; Tardito, S.; Tegoni, M.; J. Inorg. Biochem. 2005, 99, 1573.

82. Alam, J. J.; Trends Biotechnol. 2003, 21, 479.

83. Fischer, U.; Schulze-Osthoff, K.; Pharmacol. Rev. 2005, 57, 187.

84. Armstrong, J. S.; Br. J. Pharmacol. 2006, 147, 239.

85. Hail Jr, N.; Apoptosis 2005, 10, 687.

86. Levitzki, A.; Gazi, A.; Science 1995, 267, 1982.

87. Messaoudi, S.; Sancelme, M.; Polard-Housset, V.; Aboab, B.;Moreau, P.; Prudhomme, M.; Eur. J. Med. Chem. 2004, 39, 453.

88. Frein, D.; Schildknecht, S.; Bachschmid, M.; Ullrich, V.; Biochem. Pharmacol. 2005, 70, 811.

89. Nakashima, I.; Takeda, K; Kawamoto, Y.; Okuno, Y.; Kato, M.; Suzuki, H.; Arch. Biochem. Biophys. 2005, 434, 3.

90. Ciriolo, M. R.; Antioxid. Redox Signaling 2005, 7, 432.

91. Wang, T.; Guo, Z.; Curr. Med. Chem. 2006, 13, 525.

92. Arciello, M.; Rotilio, G.; Rossi, L.; Biochem. Biophys. Res. Commun. 2005, 327, 454.

Received: June 13, 2006

Published on the web: November 14, 2006

FAPESP helped in meeting the publication costs of this article. 